\title{
Inferring ozone production in an urban atmosphere using measurements of peroxynitric acid
}

\author{
K. M. Spencer ${ }^{1}$, D. C. McCabe ${ }^{2, *}$, J. D. Crounse ${ }^{1}$, J. R. Olson ${ }^{3}$, J. H. Crawford ${ }^{3}$, A. J. Weinheimer ${ }^{4}$, D. J. Knapp ${ }^{4}$, \\ D. D. Montzka ${ }^{4}$, C. A. Cantrell ${ }^{4}$, R. S. Hornbrook ${ }^{4}$, R. L. Mauldin $\mathrm{III}^{4}$, and P. O. Wennberg ${ }^{2,5}$ \\ ${ }^{1}$ Division of Chemistry and Chemical Engineering, California Institute of Technology, Pasadena, CA, USA \\ ${ }^{2}$ Division of Geological and Planetary Sciences, California Institute of Technology, Pasadena, CA, USA \\ ${ }^{3}$ NASA Langley Research Center, Hampton, VA, USA \\ ${ }^{4}$ National Center for Atmospheric Research, Boulder, CO, USA \\ ${ }^{5}$ Division of Engineering and Applied Science, California Institute of Technology, Pasadena, CA, USA \\ * current address: AAAS Science \& Technology Policy Fellow, United States Environmental Protection Agency, \\ Washington, DC, USA
}

Received: 1 December 2008 - Published in Atmos. Chem. Phys. Discuss.: 28 January 2009

Revised: 28 April 2009 - Accepted: 15 May 2009 - Published: 8 June 2009

\begin{abstract}
Observations of peroxynitric acid $\left(\mathrm{HO}_{2} \mathrm{NO}_{2}\right)$ obtained simultaneously with those of $\mathrm{NO}$ and $\mathrm{NO}_{2}$ provide a sensitive measure of the ozone photochemical production rate. We illustrate this technique for constraining the ozone production rate with observations obtained from the NCAR C-130 aircraft platform during the Megacity Initiative: Local and Global Research Observations (MILAGRO) intensive in Mexico during the spring of 2006. Sensitive and selective measurements of $\mathrm{HO}_{2} \mathrm{NO}_{2}$ were made in situ using chemical ionization mass spectrometry (CIMS). Observations were compared to modeled $\mathrm{HO}_{2} \mathrm{NO}_{2}$ concentrations obtained from the NASA Langley highly-constrained photochemical time-dependent box model. The median observedto-calculated ratio of $\mathrm{HO}_{2} \mathrm{NO}_{2}$ is 1.18. At $\mathrm{NO}_{\mathrm{x}}$ levels greater than $15 \mathrm{ppbv}$, the photochemical box model underpredicts observations with an observed-to-calculated ratio of $\mathrm{HO}_{2} \mathrm{NO}_{2}$ of 1.57. As a result, we find that at high $\mathrm{NO}_{\mathrm{x}}$, the ozone production rate calculated using measured $\mathrm{HO}_{2} \mathrm{NO}_{2}$ is faster than predicted using accepted photochemistry. Inclusion of an additional $\mathrm{HO}_{\mathrm{x}}$ source from the reaction of excited state $\mathrm{NO}_{2}$ with $\mathrm{H}_{2} \mathrm{O}$ or reduction in the rate constant of the reaction of $\mathrm{OH}$ with $\mathrm{NO}_{2}$ improves the agreement.
\end{abstract}

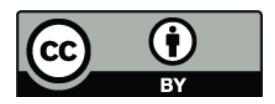

Correspondence to: K. M. Spencer (kspencer@caltech.edu)

\section{Introduction}

Peroxynitric acid, $\mathrm{HO}_{2} \mathrm{NO}_{2}$, is an important reservoir of both $\mathrm{HO}_{\mathrm{x}}\left(\mathrm{HO}_{\mathrm{x}}=\mathrm{OH}+\mathrm{HO}_{2}\right)$ and $\mathrm{NO}_{\mathrm{x}}\left(\mathrm{NO}_{\mathrm{x}}=\mathrm{NO}+\mathrm{NO}_{2}\right)$ radicals. These radicals are of primary atmospheric importance as they influence the production and degradation of tropospheric ozone and numerous volatile organic compounds (Murphy et al., 2004). Ozone production in urban environments is initiated by $\mathrm{OH}$ radicals and requires sunlight, $\mathrm{NO}_{\mathrm{x}}$, and hydrocarbons. The relative amounts of these species control the rate of ozone production (Seinfeld and Pandis, 2006).

The only known pathway for the formation of $\mathrm{HO}_{2} \mathrm{NO}_{2}$ in the atmosphere is the association reaction of $\mathrm{HO}_{2}$ and $\mathrm{NO}_{2}$, Reaction (R1) (Niki et al., 1977). $\mathrm{HO}_{2} \mathrm{NO}_{2}$ is lost via thermal decomposition, Reaction (R1) (Graham et al., 1977, 1978; Zabel et al., 1995; Gierczak et al., 2005); UV and visible/near-IR photolysis, Reaction (R2) (Macleod et al., 1988; Roehl et al., 2002; Knight et al., 2002); and reaction with the OH radical, Reaction (R3) (Trevor et al., 1982; Smith et al., 1984; Barnes et al., 1986; Jimenez et al., 2004).

$$
\begin{aligned}
& \mathrm{HO}_{2}+\mathrm{NO}_{2}+\mathrm{M} \rightleftharpoons \mathrm{HO}_{2} \mathrm{NO}_{2}+\mathrm{M} \\
& \mathrm{HO}_{2} \mathrm{NO}_{2}+\mathrm{h} v \rightarrow \text { products } \\
& \mathrm{HO}_{2} \mathrm{NO}_{2}+\mathrm{OH} \rightarrow \mathrm{H}_{2} \mathrm{O}+\mathrm{NO}_{2}+\mathrm{O}_{2}
\end{aligned}
$$

The relative importance of the $\mathrm{HO}_{2} \mathrm{NO}_{2}$ sinks depends on temperature, pressure, $\mathrm{OH}$ radical concentration, and the

Published by Copernicus Publications on behalf of the European Geosciences Union. 
UV/IR radiation field. The lifetime of $\mathrm{HO}_{2} \mathrm{NO}_{2}$ with respect to thermal decomposition varies due to the strong temperature dependence of this process (Kim et al., 2007). As temperature decreases, loss due to photolysis and reaction with $\mathrm{OH}$ radical become increasingly important. At altitudes greater than $7 \mathrm{~km}$, photolysis and reaction with $\mathrm{OH}$ become the dominant loss mechanisms (Roehl et al., 2002). The formation of $\mathrm{HO}_{2} \mathrm{NO}_{2}$ followed by its loss via reaction with $\mathrm{OH}$ forms a $\mathrm{NO}_{\mathrm{x}}$-catalyzed sink of $\mathrm{HO}_{\mathrm{x}}$ radicals (Roehl et al., 2002).

The role of $\mathrm{HO}_{2} \mathrm{NO}_{2}$ in photochemistry of the lower troposphere has been less explored, in part because of a paucity of observations of this compound. In situ measurements of $\mathrm{HO}_{2} \mathrm{NO}_{2}$ have been obtained previously in the free troposphere during the 2004 INTEX-NA campaign (Kim et al., 2007) and in Antarctica (Slusher et al., 2001). An indirect estimate of the $\mathrm{HO}_{2} \mathrm{NO}_{2}$ abundance was obtained from the sum of peroxynitrate observations during the 2000 TOPSE campaign (Murphy et al., 2004).

Here, we present in situ measurements of $\mathrm{HO}_{2} \mathrm{NO}_{2}$ in and around Mexico City. These measurements were made in March of 2006 from the NCAR C-130 aircraft platform during the MILAGRO field experiment. One goal of the MILAGRO mission, and the focus of the C-130 flights, was to investigate the processing and outflow of pollution from Mexico City. Most flights occurred during the daytime hours at altitudes below $7 \mathrm{~km}$ and temperatures between 260 and $300 \mathrm{~K}$. The majority of the data are between 270 and $283 \mathrm{~K}$. This study is limited to six of the MILAGRO flights (8, $22,23,26,28$, and 29 March) during which all necessary species were measured. A photochemical steady-state approximation of $\mathrm{HO}_{2} \mathrm{NO}_{2}$ under MILAGRO conditions is discussed, and measured $\mathrm{HO}_{2} \mathrm{NO}_{2}$ concentrations are compared to those predicted by the NASA LaRC box model. A simplified method of estimating the rate of ozone production using $\mathrm{HO}_{2} \mathrm{NO}_{2}$ is compared to full NASA LaRC box model calculations of the rate of ozone production.

\section{Method}

\subsection{Instrumentation}

$\mathrm{NO}$ and $\mathrm{NO}_{2}$ mixing ratios were measured by photofragmentation/chemiluminescence. The precision of these measurements is $\sim 15 \mathrm{pptv}$ and the overall uncertainties are $\pm(15+7 \%$ of the mixing ratio) pptv and $\pm(15+10 \%$ of the mixing ratio) pptv, respectively (Campos et al., 1998; Weinheimer et al., 1998). $\mathrm{CH}_{2} \mathrm{O}$ mixing ratios were measured by tunable diode laser absorption spectroscopy with an uncertainty of $15 \%$ (Fried et al., 2003; Wert et al., 2003). $\mathrm{HO}_{2}$ mixing ratios were determined by chemical-conversion/chemical ionization mass spectroscopy with an uncertainty of $35 \%$ (Cantrell et al., 2003). Non-methane hydrocarbons (NMHC) were measured using whole air sampling (WAS) and subse- quent analysis was conducted by gas chromatography/mass spectrometry/flame ionization detection/electron capture detection (Colman et al., 2001; Blake et al., 2003). $\mathrm{H}_{2} \mathrm{O}$ mixing ratios were calculated using the ambient water vapor pressure and corrected static pressure. These measurements and the ambient temperature measurements are included in the NCAR C-130 standard airborne scientific measurements and are discussed in RAF Bulletin No. 9 (Miller and Friesen, 1985). The full details of measurements taken during MILAGRO from the NCAR C-130 aircraft platform can be found at http://mirage-mex.acd.ucar.edu/Measurements/ C130/index.shtml.

$\mathrm{HO}_{2} \mathrm{NO}_{2}$ measurements were made using the Caltech chemical ionization mass spectrometry (CIMS) instrument. The instrument has been described in detail previously by Crounse et al. (2006). Briefly, the Caltech CIMS consists of a flow tube controlled at $35 \mathrm{mbar}$ total pressure where a reagent ion, $\mathrm{CF}_{3} \mathrm{O}^{-}$, interacts with ambient air diluted 1:4 with dry nitrogen. Ions are sampled from the flow tube into a quadrupole mass filter and detected with a channel electron multipler. Each mass-to-charge ratio is observed for $\sim 0.5 \mathrm{~s}$. $\mathrm{HO}_{2} \mathrm{NO}_{2}$ masses were monitored every $\sim 15 \mathrm{~s}$.

Negative ion chemistry of $\mathrm{CF}_{3} \mathrm{O}^{-}$has been shown to provide sensitive and selective detection of many inorganic and organic acids (Huey et al., 1996; Amelynck et al., 2000a,b; Crounse et al., 2006) and was exploited in this work to detect $\mathrm{HO}_{2} \mathrm{NO}_{2}$. The reaction of $\mathrm{CF}_{3} \mathrm{O}^{-}$with acids follows several pathways. Reaction with strong acids proceeds via fluoride ion transfer (Huey et al., 1996) while reaction with weaker acids yields clusters of reagent ion and analyte (Amelynck et al., 2000a). $\mathrm{HO}_{2} \mathrm{NO}_{2}$ reacts with $\mathrm{CF}_{3} \mathrm{O}^{-}$via fluoride ion transfer through Reaction (R4), clustering through Reaction (R5) (Crounse et al., 2006), and HF elimination through Reaction (R6), providing three distinct ion signals. Reactions (R4-R6) are complicated by competing reactions with $\mathrm{CF}_{3} \mathrm{O}^{-}$water cluster $\left(\mathrm{CF}_{3} \mathrm{O}^{-} \cdot \mathrm{H}_{2} \mathrm{O}\right)$.

$$
\begin{aligned}
& \mathrm{CF}_{3} \mathrm{O}^{-}+\mathrm{HO}_{2} \mathrm{NO}_{2} \rightarrow \mathrm{HF} \cdot \mathrm{OONO}_{2}^{-}(\mathrm{m} / \mathrm{z}, 98)+\mathrm{CF}_{2} \mathrm{O} \\
& \mathrm{CF}_{3} \mathrm{O}^{-}+\mathrm{HO}_{2} \mathrm{NO}_{2} \rightarrow \mathrm{CF}_{3} \mathrm{O}^{-} \cdot \mathrm{HO}_{2} \mathrm{NO}_{2}(\mathrm{~m} / \mathrm{z}, 164) \\
& \mathrm{CF}_{3} \mathrm{O}^{-}+\mathrm{HO}_{2} \mathrm{NO}_{2} \rightarrow \mathrm{CF}_{2} \mathrm{O} \cdot \mathrm{OONO}_{2}{ }^{-}(\mathrm{m} / \mathrm{z} 144)+\mathrm{HF}
\end{aligned}
$$

\subsubsection{Sensitivity and calibration}

Due to differences in reactivity of $\mathrm{CF}_{3} \mathrm{O}^{-}$and its water cluster, the sensitivity of the CIMS instrument to the ion products of the three channels, Reactions (R4, R5, R6), is dependent on the mixing ratio of water vapor in the flow tube (Crounse et al., 2006). This dependence is quantified via laboratory measurements. A small quantity of $\mathrm{HO}_{2} \mathrm{NO}_{2}$ was introduced into the flow tube. The flow tube humidity was controlled using mass flow controllers to adjust the ratio of air saturated with water vapor to dry zero air. Humidity was quantified by Fourier Transform Infrared (FTIR) spectroscopy using HITRAN line lists (Rothman et al., 2005) and the commercial 
spectral manipulation software package GRAMS (Galactic Industries Inc.). The sensitivity of the instrument to the fluoride ion transfer and cluster channels of $\mathrm{HO}_{2} \mathrm{NO}_{2}$ as a function of $\mathrm{H}_{2} \mathrm{O}$ mixing ratio in the flow tube was determined and is presented in Fig. 1. Sensitivity is expressed in ion counts, normalized by the ion counts of the +1 isotopes of the reagent ions, ${ }^{13} \mathrm{CF}_{3} \mathrm{O}^{-}$and ${ }^{13} \mathrm{CF}_{3} \mathrm{O}^{-} \cdot \mathrm{H}_{2} \mathrm{O}$, per pptv of $\mathrm{HO}_{2} \mathrm{NO}_{2}$. The yield of Reaction (R6) is typically one-third that of Reaction (R5). Due to the low reaction yield, Reaction (R6) is not used to quantify the ambient observations of $\mathrm{HO}_{2} \mathrm{NO}_{2}$.

During calibration, the concentration of $\mathrm{HO}_{2} \mathrm{NO}_{2}$ in the flow tube was determined by thermally decomposing the $\mathrm{HO}_{2} \mathrm{NO}_{2}$ into $\mathrm{NO}_{2}$, Reaction (R1), and quantifying the resultant $\mathrm{NO}_{2}$ using CIMS with $\mathrm{SF}_{6}^{-}$as the reagent ion through Reaction (R7) (Huey et al., 1995):

$\mathrm{SF}_{6}^{-}+\mathrm{NO}_{2} \rightarrow \mathrm{SF}_{6}+\mathrm{NO}_{2}^{-}(m / z 46)$

$\mathrm{NO}_{2}$ is not detected with high sensitivity using $\mathrm{CF}_{3} \mathrm{O}^{-}$.

Synthesis of $\mathrm{HO}_{2} \mathrm{NO}_{2}$ was performed offline using the procedure described in Roehl et al. (2002); gas-phase $\mathrm{HO}_{2} \mathrm{NO}_{2}$ was produced by flowing dry $\mathrm{N}_{2}$ over the solution of $\mathrm{HO}_{2} \mathrm{NO}_{2}$. A small portion of this flow was directed through a critical orifice into a PTFE three-way valve, which directed the flow through either a heated or unheated glass inlet tube $(6 \mathrm{~mm} \mathrm{OD})$. The heated inlet tube was kept at $190^{\circ} \mathrm{C}$, a temperature at which $99.8 \%$ of the $\mathrm{HO}_{2} \mathrm{NO}_{2}$ decomposed, as determined by monitoring the signal with $\mathrm{CF}_{3} \mathrm{O}^{-}$at $m / z$ 98. The unheated inlet was maintained at room temperature. The sensitivity of the CIMS to $\mathrm{NO}_{2}$ was quantified using a dilute mixture of $\mathrm{NO}_{2}$ in $\mathrm{N}_{2}$; the concentration of $\mathrm{NO}_{2}$ in this mixture was quantified with FTIR using HITRAN line lists (Rothman et al., 2005) and the commercial spectral manipulation software package GRAMS (Galactic Industries Inc.).

The CIMS sensitivity to $\mathrm{HO}_{2} \mathrm{NO}_{2}$ was determined by back-to-back measurements of the products of Reactions (R4), (R5), and (R7). $\mathrm{HO}_{2} \mathrm{NO}_{2}$ was added through the room temperature inlet and measured using $\mathrm{CF}_{3} \mathrm{O}^{-}$as the reagent ion. Next, $\mathrm{HO}_{2} \mathrm{NO}_{2}$ was added through the heated inlet and $\mathrm{NO}_{2}$ was measured using $\mathrm{SF}_{6}^{-}$as the reagent ion through Reaction (R7). Background $\mathrm{NO}_{2}$ from $\mathrm{NO}_{2}$ impurity in the $\mathrm{HO}_{2} \mathrm{NO}_{2}$ solution was measured using $\mathrm{SF}_{6}^{-}$by passing the $\mathrm{HO}_{2} \mathrm{NO}_{2}$ through the room temperature inlet; this background signal was subtracted from the $\mathrm{NO}_{2}$ signal when the heated inlet was used. The signals from Reactions (R4) and (R5) obtained using the room temperature inlet were also corrected for the small amount of $\mathrm{HO}_{2} \mathrm{NO}_{2}$ that did not dissociate in the heated inlet and other backgrounds (see below) by monitoring those masses using $\mathrm{CF}_{3} \mathrm{O}^{-}$as the reagent ion with the heated inlet in use. This procedure was repeated at a number of humidities to obtain water-dependent calibration functions for each ion product. Post-mission laboratory calibrations for $\mathrm{HO}_{2} \mathrm{NO}_{2}$ were conducted. During flight, isotopically labeled $\mathrm{HNO}_{3}$ was periodically added to

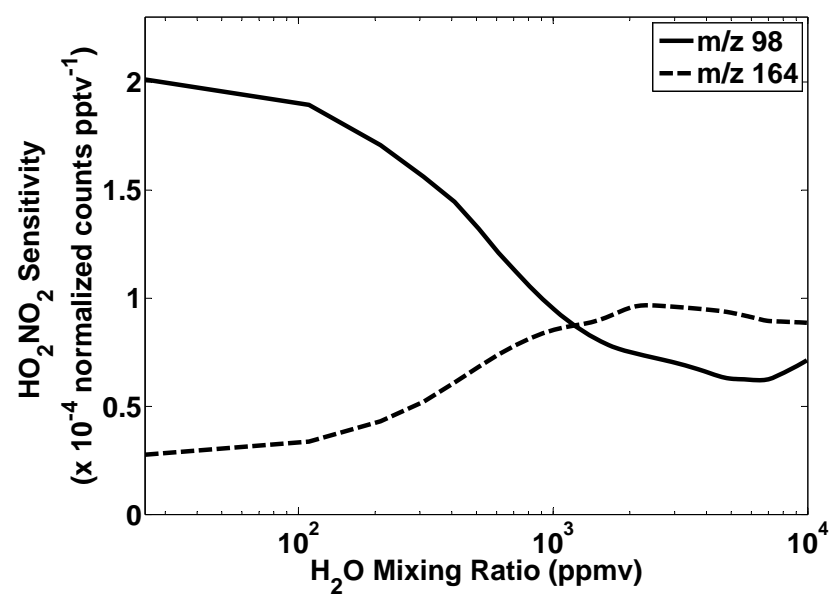

Fig. 1. Sensitivity curves for $\mathrm{m} / \mathrm{z}, 98$ (solid) and $\mathrm{m} / \mathrm{z}, 164$ (dash) as a function of $\mathrm{H}_{2} \mathrm{O}$ mixing ratio in the flow tube. The sensitivity curves are used to calculate the final mixing ratios of $\mathrm{HO}_{2} \mathrm{NO}_{2}$.

the flow tube to monitor the stability of the instrument sensitivity. Sensitivity of the instrument to $\mathrm{HNO}_{3}$ was consistent and comparable during flight and laboratory calibrations indicating the sensitivity of the instrument to $\mathrm{HO}_{2} \mathrm{NO}_{2}$ was consistent.

In the absence of $\mathrm{HO}_{2} \mathrm{NO}_{2}$, ion signals at $\mathrm{m} / z, 98$ and $\mathrm{m} / \mathrm{z}, 164$ are non-zero, and these background signals must be accounted for in the data analysis. These background signals were measured during flight by periodically passing ambient air through a filter consisting of alumina pellets coated with palladium and nylon wool coated with sodium bicarbonate, quantitatively removing $\mathrm{HO}_{2} \mathrm{NO}_{2}$. This technique is described in Crounse et al. (2006).

\subsubsection{Ambient $\mathrm{HO}_{2} \mathrm{NO}_{2}$ concentration}

$\mathrm{HO}_{2} \mathrm{NO}_{2}$ concentrations are calculated from the signals observed at $\mathrm{m} / \mathrm{z} 98$ and $\mathrm{m} / \mathrm{z} 164$ after normalization by the amount of reagent ion signal, subtraction of background signals, and application of the appropriate sensitivity factor for $\mathrm{HO}_{2} \mathrm{NO}_{2}$.

Acetate in the form $\mathrm{HF} \cdot \mathrm{CH}_{3} \mathrm{C}(\mathrm{O}) \mathrm{O}^{-} \cdot \mathrm{H}_{2} \mathrm{O}$ is a known interference in the $m / z 98$ signal. $\mathrm{HF} \cdot \mathrm{CH}_{3} \mathrm{C}(\mathrm{O}) \mathrm{O}^{-} \cdot \mathrm{H}_{2} \mathrm{O}$ is seen at $\mathrm{m} / \mathrm{z} 97$, with approximately $2.5 \%$ of the $\mathrm{m} / z 97$ signal appearing at $m / z 98$ due to heavy isotopes of the ion. Because the $m / z, 97$ signal was not monitored during these flights, the interference at $\mathrm{m} / \mathrm{z}, 98$ was estimated from the monitored signal of the acetate-fluoride transfer ion $\left(\mathrm{HF} \cdot \mathrm{CH}_{3} \mathrm{C}(\mathrm{O}) \mathrm{O}^{-}\right.$) at $\mathrm{m} / z 79$ and ambient water levels, using a function derived through post-mission laboratory measurements. There are no interferences of which we are aware at $m / z$ 164. Background signals were measured (as described above) about every $15 \mathrm{~min}$ and are used to model background levels during the flight. 


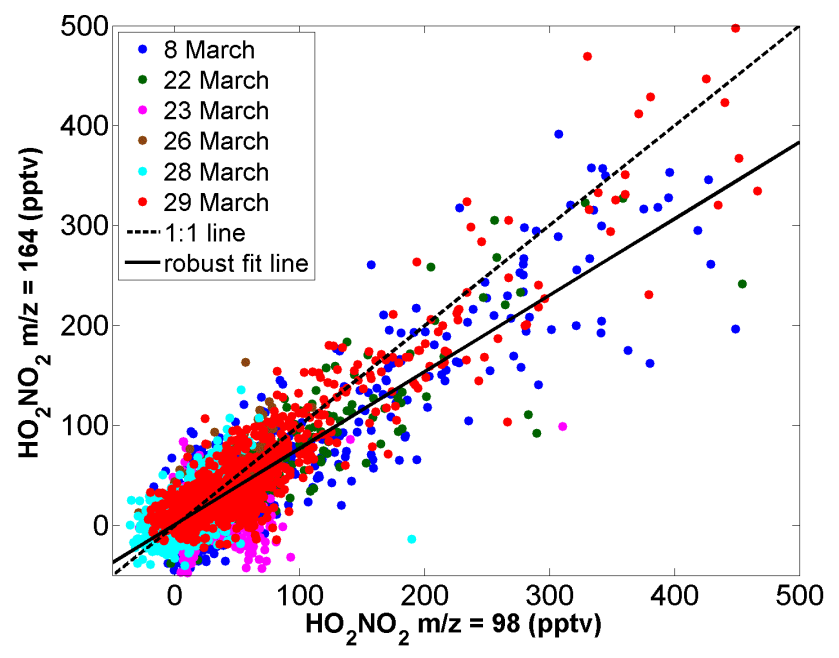

Fig. 2. $\mathrm{HO}_{2} \mathrm{NO}_{2}$ is measured with two ions: products of fluoride transfer $(m / z=98)$ and clustering $(m / z=164)$. The data are colored by flight date. The data shown are observations obtained when the measured $\mathrm{NO}_{\mathrm{y}}$ differs by less than $10 \%$ between $\mathrm{m} / \mathrm{z}, 98$ and $\mathrm{m} / \mathrm{z}, 164$ sampling times. The slope of the robust fit line is 0.76 ; the intercept is $0.90 \mathrm{pptv} ; R^{2}=0.94$. Independent measurements of $\mathrm{HO}_{2} \mathrm{NO}_{2}$ from these two ions agree very well, indicating that these masses are selective to $\mathrm{HO}_{2} \mathrm{NO}_{2}$.

A scatter plot of the independent determinations of $\mathrm{HO}_{2} \mathrm{NO}_{2}$ calculated from the $\mathrm{m} / \mathrm{z}, 98$ and the $\mathrm{m} / \mathrm{z} 164$ signals is shown in Fig. 2. During the flight, there is an $\sim 8 \mathrm{~s}$ delay between a $\mathrm{m} / \mathrm{z}, 98$ measurement and the corresponding $\mathrm{m} / z, 164$ measurement. Only observations obtained when the measured $\mathrm{NO}_{\mathrm{y}}$ differs by less than $10 \%$ between $\mathrm{m} / \mathrm{z} 98$ and $\mathrm{m} / \mathrm{z} 164$ sampling times are included in Fig. 2. The slope of the robust fit line (DuMouchel and O'Brien, 1989; Street et al., 1988) is 0.76 ; intercept is $0.90 \mathrm{pptv} ; R^{2}=0.94$. These independent measurements are in good agreement, providing confidence in the use of this ion chemistry to quantify $\mathrm{HO}_{2} \mathrm{NO}_{2}$.

The concentration of $\mathrm{HO}_{2} \mathrm{NO}_{2}$ used in the subsequent analysis is determined by combining the independent measurements from $\mathrm{m} / \mathrm{z}, 98$ and $\mathrm{m} / \mathrm{z}, 164$ as follows. When the water mixing ratio in the flow tube is less than or equal to $200 \mathrm{ppmv}$, the $\mathrm{m} / \mathrm{z} 98$ measurement is used because the sensitivity at $\mathrm{m} / \mathrm{z}, 164$ is low (Fig. 1; recall that the ambient air pulled into the flow tube is diluted 1:4 with dry $\mathrm{N}_{2}$ ). When the water mixing ratio in the flow tube is between 200 to 500 ppmv, the mean of the $\mathrm{m} / \mathrm{z} 98$ and the $\mathrm{m} / \mathrm{z}, 164$ measurements is used. At water vapor mixing ratios greater than 500 ppmv, the $m / z 164$ measurement is used exclusively. Although the sensitivity is somewhat lower at $\mathrm{m} / \mathrm{z}, 164$ than at $\mathrm{m} / \mathrm{z} 98$ for water mixing ratios between 500 to $1000 \mathrm{ppmv}$, higher backgrounds and interference from acetate at $\mathrm{m} / \mathrm{z} 98$ make the cluster ion $(\mathrm{m} / \mathrm{z}, 164)$ a more robust measure of $\mathrm{HO}_{2} \mathrm{NO}_{2}$ at these higher water mixing ratios.
The uncertainty in the PNA measurements is approximately $\pm(30 \%+30 \mathrm{pptv})$. The uncertainty reflects the sum of the precision of the data determined by the counting statistics of the ions, the variability of the background signal, and the uncertainty of the sensitivities shown in Fig. 1.

\subsection{Photochemical time-dependent box model}

Calculated concentrations of $\mathrm{HO}_{2}, \mathrm{NO}_{2}$, and $\mathrm{HO}_{2} \mathrm{NO}_{2}$ and rates of ozone production were obtained from a highly-constrained photochemical time-dependent box model (NASA Langley Research Center (LaRC) box model) (Olson et al., 2006). The modeling approach used is based on the assumption of a diurnal equilibrium (Olson et al., 2006, 2004; Frost et al., 2002; Jaegle et al., 2000). Model inputs include observations of atmospheric parameters such as temperature, pressure, water vapor, and critical long-lived chemical precursor species $\left(\mathrm{O}_{3}, \mathrm{CO}, \mathrm{NO}, \mathrm{CH}_{4}\right.$, non-methane hydrocarbons, acetone). With the exception of $\mathrm{NO}$ and the radiation field, the atmospheric state is held constant throughout the model run. NO varies diurnally; however reactive nitrogen, $\mathrm{NO}_{\mathrm{y}}=\mathrm{NO}+\mathrm{NO}_{2}+\mathrm{NO}_{3}+2 \mathrm{~N}_{2} \mathrm{O}_{5}+\mathrm{HONO}+\mathrm{HO}_{2} \mathrm{NO}_{2}$, is held constant with partitioning as determined by the model. The amount of total reactive nitrogen is determined so that NO matches the observed value at the time of the measurement. Additional constraints are implemented if data are available. These additional constraints include methanol, ethanol, $\mathrm{H}_{2} \mathrm{O}_{2}, \mathrm{CH}_{3} \mathrm{OOH}, \mathrm{HNO}_{3}, \mathrm{PAN}$, acetic acid, and formic acid. Concentrations of these species are computed by the model when data are unavailable. While a discrepancy between calculated and observed values of acetaldehyde $\left(\mathrm{CH}_{3} \mathrm{CHO}\right)$ does exist and has the potential to impact $\mathrm{HO}_{\mathrm{x}}$ levels, constraining the model to observed $\mathrm{CH}_{3} \mathrm{CHO}$ values suggests that this uncertainty propagates to impact $\mathrm{OH}$ mixing ratios by $5-10 \%$ and $\mathrm{HO}_{2}$ mixing ratios by less than a few percent.

The model chemistry includes $\mathrm{HO}_{\mathrm{x}}-\mathrm{NO}_{\mathrm{x}}-\mathrm{CH}_{4}$ gas phase reactions based on the recommendations of Atkinson et al. (2004) and Sander et al. (2003). In addition, the model uses the rate for $\mathrm{O}\left({ }^{1} \mathrm{D}\right)$ quenching by $\mathrm{N}_{2}$ suggested by Ravishankara et al. (2002), temperature dependent quantum yields for acetone photolysis from Arnold et al. (2005), and the parameterization for near-IR photolysis of $\mathrm{HO}_{2} \mathrm{NO}_{2}$ described by Roehl et al. (2002). Nonmethane hydrocarbon chemistry is based on the condensed mechanism of Lurmann et al. (1986) with modifications included to address remote low$\mathrm{NO}_{\mathrm{x}}$ conditions. Explicit chemistry is included for $\mathrm{C}_{2} \mathrm{H}_{6}$, $\mathrm{C}_{3} \mathrm{H}_{8}, \mathrm{C}_{2} \mathrm{H}_{4}$, isoprene, and benzene. $\mathrm{C}_{4}$ and higher alkanes are lumped together, as are $\mathrm{C}_{3}$ and higher alkenes, and aromatics other than benzene. Reactions of lumped $\mathrm{C}_{3}$ and higher alkenes are assumed to be predominantly propene. The assumed aldehyde product is $\mathrm{CH}_{3} \mathrm{CHO}$ and reaction rates are based on those for propene. Photolysis rate coefficients are based on spectroradiometer measurements (Shetter and Muller, 1999). The diurnal profiles of the photolysis 
rates are computed by a DISORT four-stream implementation of the Tropospheric Ultraviolet Visible (TUV) radiative transfer code (Madronich and Flocke, 1998). These calculated profiles are then normalized to match the instantaneous observations at the time of measurement.

Model calculations use the 1-min merged data set available on the INTEX-B public data archive (http://www-air. larc.nasa.gov). In this study, we limit the analysis to those points that include direct measurement of NMHCs.

\subsection{Photochemical steady-state}

Due to the short lifetime of $\mathrm{HO}_{2} \mathrm{NO}_{2}$ with respect to thermal decomposition for the conditions experienced during the MILAGRO flights, photochemical steady state of $\mathrm{HO}_{2} \mathrm{NO}_{2}$ was assumed. To verify the validity of this assumption with respect to $\mathrm{HO}_{2} \mathrm{NO}_{2}$, the model was run in a non-steady state mode. A large, polluted perturbation was introduced into the model and allowed to decay over several days. A second set of calculations was performed in which each point was solved along the decay of the plume using steady state assumptions. While some species were not in equilibrium during this model run, the mixing ratios of $\mathrm{HO}_{2} \mathrm{NO}_{2}$ were consistent with the steady state run. This is attributed to the very short lifetime of $\mathrm{HO}_{2} \mathrm{NO}_{2}$ for the temperature range in the dataset. $\mathrm{NO}_{\mathrm{x}}$ is directly input into the model while $\mathrm{HO}_{\mathrm{x}}$ varies rapidly enough to represent the instantaneous precursor condition. At photochemical steady state, production and loss of $\mathrm{HO}_{2} \mathrm{NO}_{2}$ are equal and Reactions (R1-R3) yield (Kim et al., 2007):

$\left[\mathrm{HO}_{2} \mathrm{NO}_{2}\right]_{\mathrm{ss}}=\frac{k_{1}\left[\mathrm{HO}_{2}\right]\left[\mathrm{NO}_{2}\right]}{J_{2}+k_{-1}+k_{3}[\mathrm{OH}]}$

For the conditions experienced during the MILAGRO flights, the median lifetime of $\mathrm{HO}_{2} \mathrm{NO}_{2}$ with respect to thermal decomposition was five minutes while the lifetimes with respect to reaction with $\mathrm{OH}$ and UV/IR photolysis were on the order of $10 \mathrm{~h}$ and 6 days, respectively. Under these conditions, the steady-state concentration of $\mathrm{HO}_{2} \mathrm{NO}_{2}$ simplifies to:

$\left[\mathrm{HO}_{2} \mathrm{NO}_{2}\right]_{\mathrm{ss}} \approx \frac{k_{1}\left[\mathrm{HO}_{2}\right]\left[\mathrm{NO}_{2}\right]}{k_{-1}}$

To evaluate whether the simplified assumption for steady state (Eq. 2) is robust for MILAGRO conditions, NASA LaRC box model predictions of $\mathrm{HO}_{2}$ and $\mathrm{NO}_{2}$ were used in the right-hand side of Eq. (2) to calculate $\mathrm{HO}_{2} \mathrm{NO}_{2}$ using the steady state assumption $\left(\left[\mathrm{HO}_{2} \mathrm{NO}_{2}\right]_{\mathrm{ss}}\right)$. $\left[\mathrm{HO}_{2} \mathrm{NO}_{2}\right]_{\mathrm{ss}}$ was then compared to the full diurnal equilibrium model predictions of $\mathrm{HO}_{2} \mathrm{NO}_{2}$ (shown in Fig. 3). The slope of the robust fit line (DuMouchel and O'Brien, 1989; Street et al., 1988) is 1.02 and the intercept is 0.10 pptv. $R^{2}=0.99$.

The $\mathrm{HO}_{2}$ mixing ratios measured from the $\mathrm{C}-130$ were not sufficiently precise to provide for a direct comparison between the measurements of $\mathrm{HO}_{2} \mathrm{NO}_{2}$ and the steady state

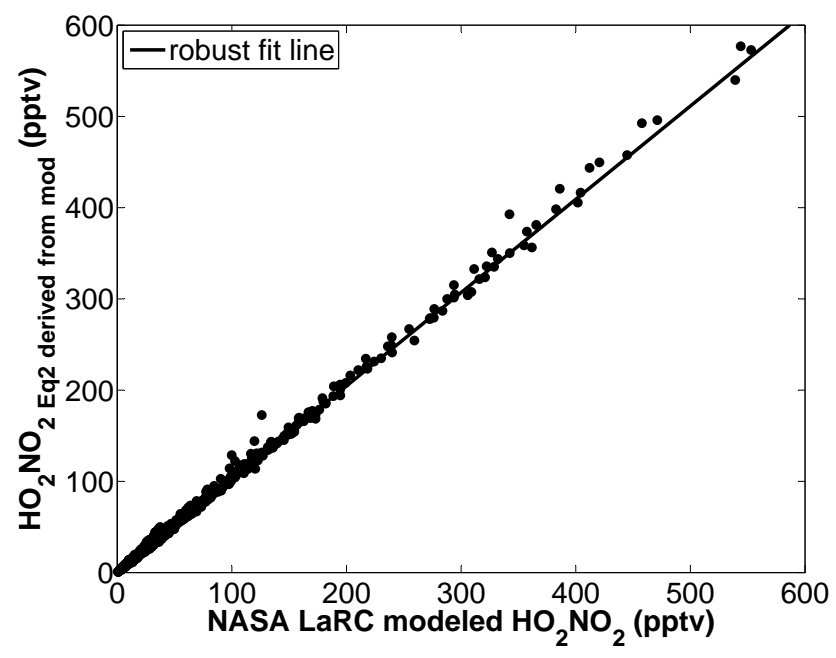

Fig. 3. $\left[\mathrm{HO}_{2} \mathrm{NO}_{2}\right]_{\mathrm{ss}}$, calculated from Eq. (2), using modeled values of $\mathrm{HO}_{2}$ and $\mathrm{NO}_{2}$ versus $\mathrm{HO}_{2} \mathrm{NO}_{2}$ predicted by the NASA LaRC box model. The slope of the robust fit line is 1.02; intercept is $0.10 \mathrm{pptv} ; R^{2}$ is 0.99 , demonstrating that Eq. (2) is a valid simplification under MILAGRO conditions.

calculation of $\left[\mathrm{HO}_{2} \mathrm{NO}_{2}\right]_{\mathrm{ss}}$ using observed $\mathrm{HO}_{2}$ and $\mathrm{NO}_{2}$. However, the mean observed concentration of $\mathrm{HO}_{2}$ was within $15 \%$ of the mean concentration of the NASA LaRC box model estimate for each of the flights used in this analysis.

\section{Comparisons with NASA LaRC photochemical box model}

An example time trace for $\mathrm{HO}_{2} \mathrm{NO}_{2}$ is illustrated in Fig. 4. During this flight (29 March 2006), the C-130 flew in and out of air masses heavily impacted by pollution from Mexico City. Variations in the measured and modeled $\mathrm{HO}_{2} \mathrm{NO}_{2}$ mixing ratio closely follow variations in $\mathrm{NO}_{2}$.

Observed $\mathrm{HO}_{2} \mathrm{NO}_{2}$ mixing ratios, colored by $\mathrm{NO}_{\mathrm{x}}$ mixing ratios, are compared to the NASA LaRC box model calculation of $\mathrm{HO}_{2} \mathrm{NO}_{2}$ mixing ratios in Fig. 5. The slope of the robust fit line is 0.81 and the intercept is $6.74 \mathrm{pptv}$. Although overall agreement is good $\left(R^{2}=0.82\right)$, there is a tendency for the model to underpredict $\mathrm{HO}_{2} \mathrm{NO}_{2}$ concentrations at $\mathrm{NO}_{\mathrm{x}}$ levels greater than $15 \mathrm{ppbv}$ (shown by the red and orange colors in Fig. 5). Underprediction of $\mathrm{HO}_{2} \mathrm{NO}_{2}$ at elevated $\mathrm{NO}_{\mathrm{x}}$ levels are in agreement with previous findings of Murphy et al. (2004) and Kim et al. (2007).

\section{Ozone production}

Photochemical ozone production is the result of oxidation of $\mathrm{CO}$ and hydrocarbons in reactions involving $\mathrm{NO}_{\mathrm{x}}$ and $\mathrm{HO}_{\mathrm{x}}$. 


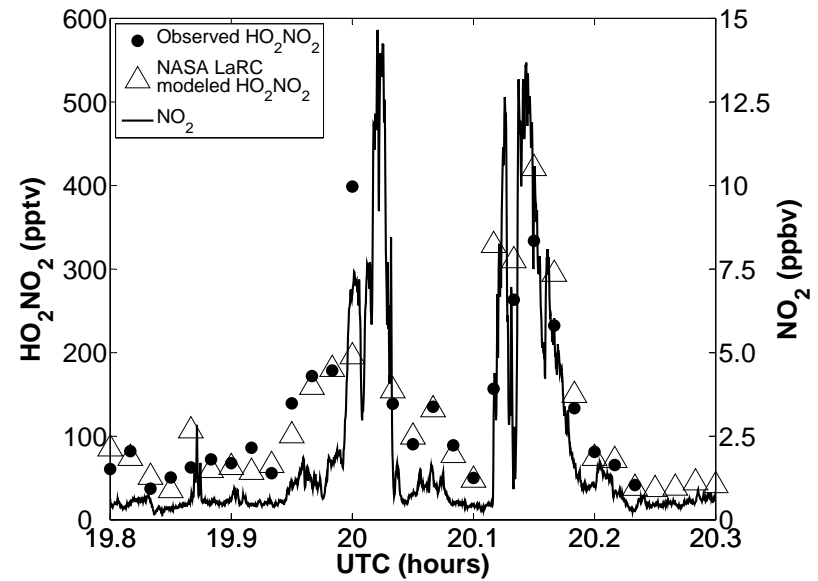

Fig. 4. Mixing ratios of $\mathrm{HO}_{2} \mathrm{NO}_{2}$ and $\mathrm{NO}_{2}$ during Flight 29 March 2006 in an air mass heavily impacted by pollution. Dots are CIMS measurements of $\mathrm{HO}_{2} \mathrm{NO}_{2}$. Triangles are NASA LaRC box model values of $\mathrm{HO}_{2} \mathrm{NO}_{2}$. The solid line is observed $\mathrm{NO}_{2}$ mixing ratio. Variations in the observed and modeled $\mathrm{HO}_{2} \mathrm{NO}_{2}$ mixing ratios closely follow variations in $\mathrm{NO}_{2}$.

The instantaneous rate of photochemical ozone production can be calculated using Eq. (3) (Jacob, 1999).

$\mathrm{P}_{\mathrm{O}_{3}}=k_{\mathrm{RO}_{2}+\mathrm{NO}}\left[\mathrm{RO}_{2}\right][\mathrm{NO}]+k_{\mathrm{HO}_{2}+\mathrm{NO}}\left[\mathrm{HO}_{2}\right][\mathrm{NO}]$

The rate constants for the reactions of peroxyradicals (including $\mathrm{HO}_{2}$ ) with $\mathrm{NO}$ are similar, so $\mathrm{P}_{\mathrm{O}_{3}}$ can be approximated as:

$\mathrm{P}_{\mathrm{O}_{3}} \approx k_{\mathrm{HO}_{2}+\mathrm{NO}}[\mathrm{NO}]\left(\left[\mathrm{RO}_{2}\right]+\left[\mathrm{HO}_{2}\right]\right)$

In polluted atmospheres, $\mathrm{HO}_{2}$ is produced primarily from the reaction of $\mathrm{RO}_{2}$ with $\mathrm{NO}$ and therefore, the sum of all non$\mathrm{HO}_{2}$ peroxy radicals will be closely and linearly related to the concentration of $\mathrm{HO}_{2}$ (e.g., Jacob, 1999).

$\mathrm{P}_{\mathrm{O}_{3}}=\mathrm{Zk}_{\mathrm{HO}_{2}+\mathrm{NO}}\left[\mathrm{HO}_{2}\right][\mathrm{NO}]$

where $Z$ is a number generally close to 2 in polluted air. With $K_{e q}=k_{1} / k_{-1}$, solving Eq. (2) for $\left[\mathrm{HO}_{2}\right]$ and substituting into Eq. (5) yields:

$\mathrm{P}_{\mathrm{O}_{3}}=\frac{\mathrm{Zk}_{\mathrm{HO}_{2}+\mathrm{NO}}\left[\mathrm{HO}_{2} \mathrm{NO}_{2}\right][\mathrm{NO}]}{\mathrm{K}_{\mathrm{eq}}\left[\mathrm{NO}_{2}\right]}$

In Fig. 6, we plot $\mathrm{P}_{\mathrm{O}_{3}}$ from the NASA LaRC box model versus $k_{\mathrm{HO}_{2}+\mathrm{NO}}\left[\mathrm{HO}_{2} \mathrm{NO}_{2}\right][\mathrm{NO}] / \mathrm{K}_{\mathrm{eq}}\left[\mathrm{NO}_{2}\right]$ to estimate $Z$. Using the NASA LaRC box model, we examined the predictions of Eq. (6). We limit this analysis to times when the solar zenith angle is $<80^{\circ}$. The slope of the polyfit fit line, $Z$, in Fig. 6 is 1.77. The correlation is high $\left(R^{2}=0.99\right)$ suggesting that the production of ozone under MILAGRO conditions can be estimated directly from Eq. (6) using measured $\mathrm{HO}_{2} \mathrm{NO}_{2}, \mathrm{NO}$, and $\mathrm{NO}_{2}$ with $Z=1.77$.

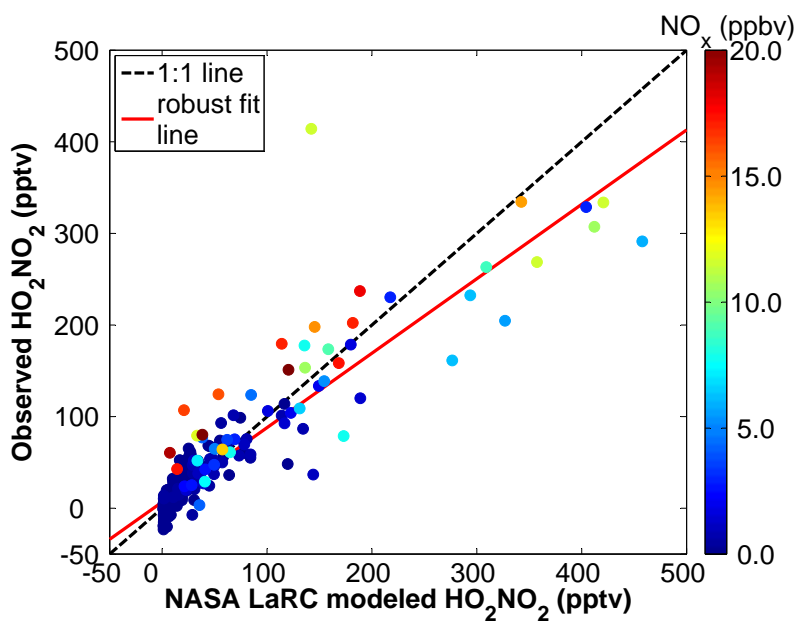

Fig. 5. Observed $\mathrm{HO}_{2} \mathrm{NO}_{2}$ versus NASA LaRC box model values of $\mathrm{HO}_{2} \mathrm{NO}_{2}$ colored by $\mathrm{NO}_{\mathrm{x}}$. The data presented are observed and modeled values at times when the model was constrained by NMHC observations. The slope of the robust fit line is 0.81 ; intercept is $6.74 \mathrm{pptv} ; R^{2}$ is 0.82 .

\section{Discussion and conclusions}

The rate of ozone production is sensitive to the rate of $\mathrm{HO}_{\mathrm{x}}$ production and the amount of $\mathrm{NO}_{\mathrm{x}}$ present. At a fixed $\mathrm{HO}_{\mathrm{x}}$ production rate, the rate of ozone production increases with $\mathrm{NO}_{\mathrm{x}}$ until $\mathrm{NO}_{\mathrm{x}}$ reaches a level where the rate of nitric acid formation via Reaction (R8) reduces $\mathrm{HO}_{\mathrm{x}}$ levels and photochemistry slows.

$\mathrm{OH}+\mathrm{NO}_{2}+\mathrm{M} \rightarrow \mathrm{HNO}_{3}+\mathrm{M}$

This behavior can be seen in the model chemistry (Fig. 7, middle panel). Ozone production rates for these MILAGRO flights calculated by the NASA LaRC box model are plotted versus $\mathrm{NO}$ levels and colored by the mixing ratio of $\mathrm{CH}_{2} \mathrm{O}$. $\mathrm{CH}_{2} \mathrm{O}$ is used here as a proxy for the $\mathrm{HO}_{\mathrm{x}}$ production rate (Seinfeld and Pandis, 2006). At low NO, the ozone production rate increases with $\mathrm{NO}$ at a fixed level of $\mathrm{CH}_{2} \mathrm{O}$, i.e., $\mathrm{NO}_{\mathrm{x}}$-limited behavior. At high $\mathrm{NO}$, the ozone production rate becomes independent of or even decreases with $\mathrm{NO}$ at a fixed level of $\mathrm{CH}_{2} \mathrm{O}$, i.e., $\mathrm{NO}_{\mathrm{x}}$-saturated behavior.

In contrast to NASA LaRC box model calculations, the rate of ozone production estimated from observed $\mathrm{HO}_{2} \mathrm{NO}_{2}$, $\mathrm{NO}$, and $\mathrm{NO}_{2}$ does not show a saturation behavior (Fig. 7, left panel). At high NO, the rate of ozone production continues to increase with $\mathrm{NO}$, in contrast to model predictions (Fig. 7, right panel). This suggests that the NASA LaRC box model underestimates the $\mathrm{HO}_{2}$ levels and therefore either the $\mathrm{HO}_{\mathrm{x}}$ production/loss rate is under/over estimated at elevated $\mathrm{NO}$ levels. This is consistent with observed $\mathrm{HO}_{2} \mathrm{NO}_{2}$ mixing ratios greater than NASA LaRC model predictions at $\mathrm{NO}_{\mathrm{x}}$ levels greater than 15 ppbv shown in Fig. 5 . 


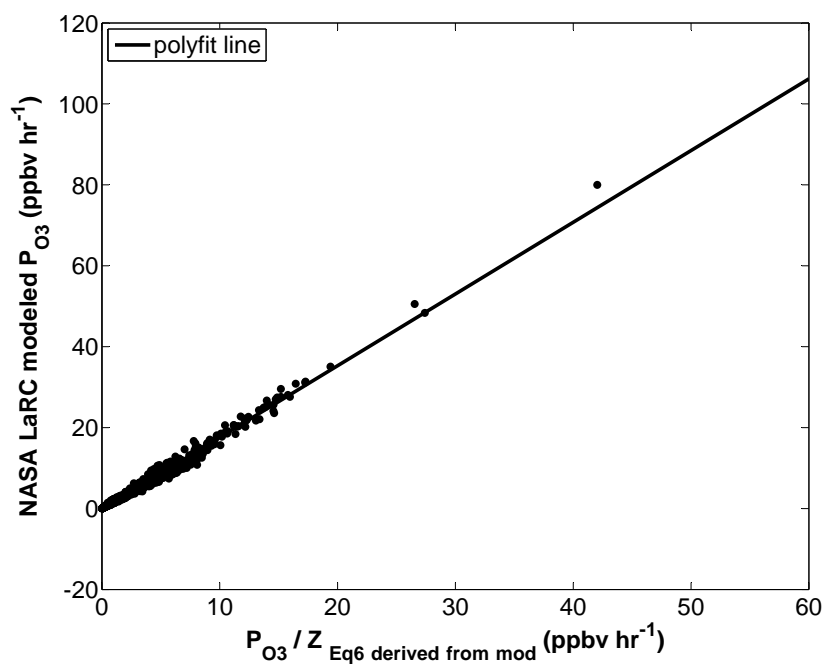

Fig. 6. The ozone production rate predicted by the NASA LaRC box model is compared to the rate of ozone production calculated using Eq. (6) and modeled values of $\mathrm{HO}_{2} \mathrm{NO}_{2}, \mathrm{NO}$, and $\mathrm{NO}_{2}$. The slope of the polyfit line, $\mathrm{Z}$, is $1.77 ; R^{2}$ is 0.99 .

Observed values of $\mathrm{HO}_{2} \mathrm{NO}_{2}$, and hence $\mathrm{HO}_{2}$, greater than those predicted by the NASA LaRC box model are consistent with a number of urban measurements of $\mathrm{HO}_{2}$. Several recent studies have pointed to possible missing $\mathrm{HO}_{\mathrm{x}}$ sources in urban air. At high $\mathrm{NO}_{\mathrm{x}}$ concentrations, $\mathrm{HO}_{2}$ levels calculated using highly constrained box models were significantly less than measured during summertime in Nashville, Birmingham, and New York City (Martinez et al., 2003; Heard et al., 2004; Emmerson et al., 2005; Ren et al., 2003) and in New York City and Tokyo in the winter (Ren et al., 2006; Kanaya et al., 2007). Martinez et al. (2003) reported daytime $\mathrm{HO}_{2}$ levels 1.56 times modeled values in Nashville in 1999. The difference between measured and modeled $\mathrm{HO}_{2}$ was positively correlated with high $\mathrm{NO}_{\mathrm{x}}$ mixing ratios. In Birmingham, England in the summer of 1999 and winter of 2000, Heard et al. (2004) observed $\mathrm{HO}_{2}$ levels 1.78 and 2.04 times modeled values, respectively. They found that the observed $\mathrm{HO}_{2}$ concentrations were particularly insensitive to changes in $\mathrm{NO}_{\mathrm{x}}$ levels. Summertime levels of $\mathrm{HO}_{2}$ in New York City in 2001 were underestimated, with observed levels 1.24 times modeled values. The difference between measured and calculated $\mathrm{HO}_{2}$ depended on the time of day. At midday, the observed and modeled values were found to agree very well while the model tended to underestimate the observations when $\mathrm{NO}_{\mathrm{x}}$ was high, usually during the morning hours (Ren et al., 2003). Similar results were found in Tokyo during the winter of 2004. Daytime $\mathrm{HO}_{2}$ concentrations were underestimated, with observed $\mathrm{HO}_{2}$ levels 2.08 times modeled values. These comparisons were sensitive to the assumed hydrocarbon levels. When the concentrations of alkenes and reactive alkanes used in the model were in-

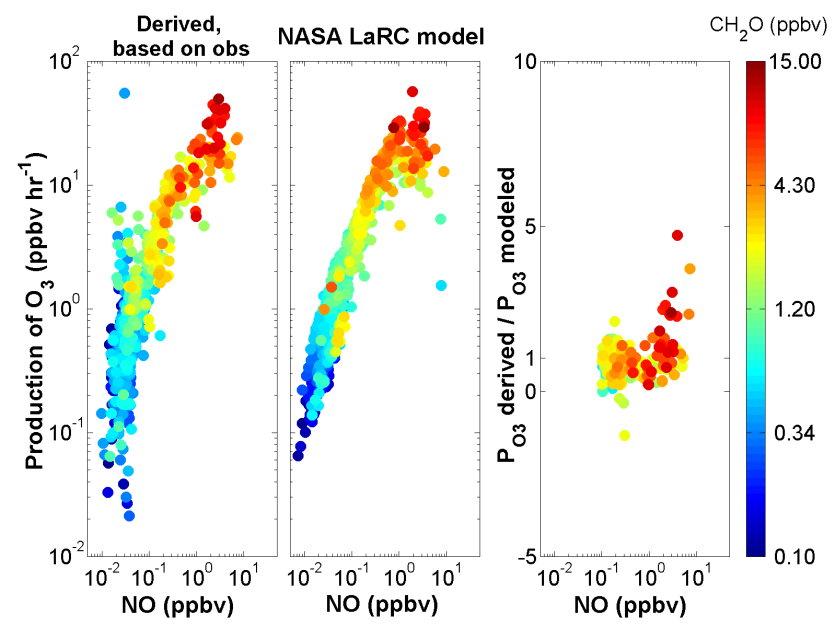

Fig. 7. $\mathrm{P}_{\mathrm{O}_{3}}$ derived from Eq. (6) and based on measurements of $\mathrm{HO}_{2} \mathrm{NO}_{2}$ and $\mathrm{NO}_{\mathrm{x}}$ versus observed $\mathrm{NO}$, colored by observed $\mathrm{CH}_{2} \mathrm{O}$ are shown in the left panel. NASA LaRC box model predictions of $\mathrm{P}_{\mathrm{O}_{3}}$ versus modeled $\mathrm{NO}$, colored by modeled $\mathrm{CH}_{2} \mathrm{O}$ are shown in the middle panel. The ratio of derived $\mathrm{P}_{\mathrm{O}_{3}}$, based on measurements to NASA LaRC box model predictions of $\mathrm{P}_{\mathrm{O}_{3}}$ for observed NO greater than 100 pptv, colored by observed $\mathrm{CH}_{2} \mathrm{O}$ are shown in the right panel.

creased by factors of 3 and 5 , respectively, the observed-tomodeled $\mathrm{HO}_{2}$ ratio decreased to 1.13. Continued underestimation of $\mathrm{HO}_{2}$ concentrations occurred at high $\mathrm{NO}_{\mathrm{x}}$ mixing ratios (Kanaya et al., 2007). The higher than expected levels of $\mathrm{HO}_{2}$ suggest higher rates of ozone production than can be accounted for using known chemistry.

It should be noted that the discrepancy between observed and modeled values of $\mathrm{HO}_{2} \mathrm{NO}_{2}$ at high $\mathrm{NO}_{\mathrm{x}}$ found in this study appears to be distinct from the underprediction of $\mathrm{HO}_{\mathrm{x}}$ values correlated with isoprene. Ren et al. (2008) found the observed-to-modeled $\mathrm{OH}$ ratio in the boundary layer to be strongly dependent on isoprene during the INTEX-NA summer 2004 campaign, with divergence occurring at isoprene levels greater than $100 \mathrm{pptv}$. Isoprene mixing ratios were well below 100 pptv for the vast majority of the data used in this analysis.

Not all studies have found excess $\mathrm{HO}_{2}$. Indeed, several studies have found overpredictions of $\mathrm{HO}_{2}$ levels by photochemical box models even at high $\mathrm{NO}_{\mathrm{x}}$ concentrations. $\mathrm{HO}_{2}$ concentrations were overestimated in the Los Angeles basin, Mexico City, and summertime Tokyo (George et al., 1999; Shirley et al., 2006; Kanaya et al., 2007). George et al. (1999) reported daytime $\mathrm{HO}_{2}$ levels 0.67 times calculated values downwind of Los Angeles in 1993. The agreement of observed and calculated $\mathrm{HO}_{2}$ was quite good in the early morning hours, but calculated $\mathrm{HO}_{2}$ concentrations were found to be significantly higher than observations during midday. In Mexico City in 2003, Shirley et al. (2006) determined that observations of $\mathrm{HO}_{2}$ were 0.79 times calculated values of 


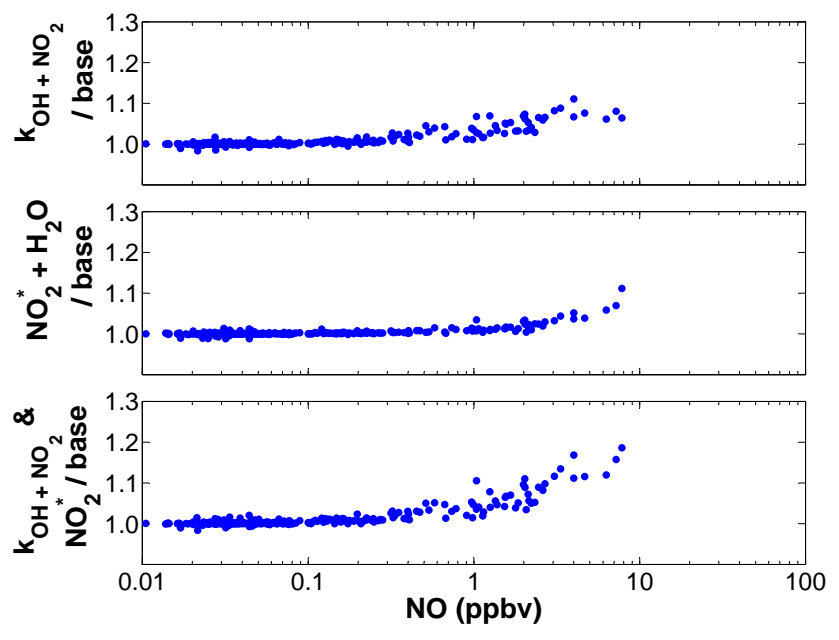

Fig. 8. Three different variations of the base model were investigated. The mixing ratio of $\mathrm{HO}_{2} \mathrm{NO}_{2}$ was calculated 1. using the $2000 \mathrm{JPL}$ recommended rate constant for $\mathrm{OH}+\mathrm{NO}_{2}$, 2. including the reaction $\mathrm{NO}_{2}^{*}+\mathrm{H}_{2} \mathrm{O} \rightarrow \mathrm{OH}+\mathrm{HONO}$, and 3. using both the 2000 JPL recommended rate constant and the $\mathrm{NO}_{2}^{*}$ reaction. The y-axis is the ratio of $\mathrm{HO}_{2} \mathrm{NO}_{2}$ mixing ratio as calculated using a model variation to that calculated using the base model. Use of the $2000 \mathrm{JPL}$ recommended rate constant for $\mathrm{OH}+\mathrm{NO}_{2}$ and inclusion of the $\mathrm{NO}_{2}^{*}+\mathrm{H}_{2} \mathrm{O}$ reaction result in higher $\mathrm{HO}_{2} \mathrm{NO}_{2}$ mixing ratios than calculated by the base model. This leads to better agreement between measured and calculated $\mathrm{HO}_{2} \mathrm{NO}_{2}$.

$\mathrm{HO}_{2}$ during the midday. However, they also calculated an observed-to-modeled ratio of 1.17 during morning rush hour, coinciding with the morning rush hour peak in $\mathrm{NO}_{\mathrm{x}}$ concentrations. Unlike wintertime findings, summertime $\mathrm{HO}_{2}$ concentrations in Tokyo were overestimated. An observed-tomodeled $\mathrm{HO}_{2}$ ratio of 0.78 was reported. Trends at high $\mathrm{NO}_{\mathrm{x}}$ levels were not discussed as NO mixing ratios greater than $20 \mathrm{ppbv}$ were not seen during this sampling period (Kanaya et al., 2007).

$\mathrm{HO}_{2}, \mathrm{HO}_{2} \mathrm{NO}_{2}$, and hence the rate of ozone production may be underpredicted at high $\mathrm{NO}$ due to errors in calculated $\mathrm{NO}_{\mathrm{x}}$-dependent $\mathrm{HO}_{\mathrm{x}}$ sources and sinks. We have investigated several possible sources of error. One possibility is an overestimate of the rate constant of Reaction (R8), a sink of $\mathrm{HO}_{\mathrm{x}}$. The accepted rate constant for Reaction (R8) has been subject to numerous revisions in the last decade (DeMore et al., 1997; Sander et al., 2000, 2003, 2006). In addition, a recommended rate constant for the reaction of $\mathrm{OH}$ and $\mathrm{NO}_{2}$ to form pernitrous acid (HOONO) is included for the first time in the 2006 JPL critical evaluation. Recent laboratory work at Jet Propulsion Laboratory and California Institute of Technology suggests that the 2000 JPL critical evaluation recommendation (Sander et al., 2000) may be closer to the true rate of Reaction (R8) (Okumura and Sander, 2005) than the current recommendation (Sander et al., 2006). The 2000 JPL critical evaluation recommended rate constant for Reac- tion (R8) is approximately $30 \%$ lower for MILAGRO conditions than the current evaluation. The explicit rate constant for $\mathrm{HNO}_{3}$ formation was used in the model. The model does not include the $\mathrm{HOONO}$ branch of the $\mathrm{OH}+\mathrm{NO}_{2}+\mathrm{M}$ reaction due to the short lifetime (seconds to minutes) of HOONO under MILAGRO conditions. The formation and breakdown of HOONO is considered to be a null cycle under these conditions (Fry et al., 2004). A reduction in the rate constant for Reaction (R8) leads to an increase in $\mathrm{OH}$ and $\mathrm{NO}_{2}$ mixing ratios, leading to an increase in $\mathrm{HO}_{2} \mathrm{NO}_{2}$ levels. To test the importance of this modified rate constant on $\mathrm{HO}_{2} \mathrm{NO}_{2}$ levels, the $2000 \mathrm{JPL}$ critical evaluation recommended rate constant for Reaction (R8) was substituted into the model. Figure 8 (top panel) illustrates the sensitivity of the modeled $\mathrm{HO}_{2} \mathrm{NO}_{2}$ mixing ratio to a change in the rate constant for Reaction (R8). At high NO levels, use of the 2000 JPL recommended rate constant increases the mixing ratio of calculated $\mathrm{HO}_{2} \mathrm{NO}_{2}$, leading to better agreement between measured and calculated $\mathrm{HO}_{2} \mathrm{NO}_{2}$.

$\mathrm{HO}_{2} \mathrm{NO}_{2}$ mixing ratios and hence rate of ozone production may also be underpredicted at high $\mathrm{NO}_{\mathrm{x}}$ due to missing calculated $\mathrm{HO}_{\mathrm{x}}$ sources at high $\mathrm{NO}_{\mathrm{x}}$. Li et al. (2008) recently reported significant $\mathrm{HO}_{\mathrm{x}}$ production from the reaction of excited-state $\mathrm{NO}_{2}\left(\mathrm{NO}_{2}^{*}\right)$ with $\mathrm{H}_{2} \mathrm{O}$ :

$\mathrm{NO}_{2}^{*}+\mathrm{H}_{2} \mathrm{O} \rightarrow \mathrm{OH}+\mathrm{HONO}$

$\mathrm{NO}_{2}^{*}$ is formed through the excitation of $\mathrm{NO}_{2}$ at wavelengths longer than $420 \mathrm{~nm}$. These direct and indirect (via HONO photolysis) $\mathrm{OH}$ sources lead to increased concentrations of $\mathrm{HO}_{\mathrm{x}}$ at elevated $\mathrm{NO}_{\mathrm{x}}$ levels. Including this process in the box model, using the rate of Reaction (R9) determined by $\mathrm{Li}$ et al., improves agreement with observed $\mathrm{HO}_{2} \mathrm{NO}_{2}$. As seen in Fig. 8 (middle panel), the inclusion of Reaction (R9) increases the mixing ratio of modeled $\mathrm{HO}_{2} \mathrm{NO}_{2}$, again leading to better agreement between measured and modeled $\mathrm{HO}_{2} \mathrm{NO}_{2}$. Including both the reduced rate of Reaction (R8) and the $\mathrm{Li}$ et al. (2008) process leads to increased levels of modeled $\mathrm{HO}_{2} \mathrm{NO}_{2}$ (Fig. 8, bottom panel). Increased levels of calculated $\mathrm{HO}_{2} \mathrm{NO}_{2}$ are in better agreement with observations. These two recently suggested ideas lead to better, not perfect, agreement between observed and calculated $\mathrm{HO}_{2} \mathrm{NO}_{2}$.

The transition to $\mathrm{NO}_{\mathrm{x}}$ saturation appears to occur at higher $\mathrm{NO}_{\mathrm{x}}$ levels than estimated by the NASA LaRC box model for Mexico City. This may have implications for engineering of improvements in air quality in the basin. If generally true, it suggests that further $\mathrm{NO}_{\mathrm{x}}$ controls will yield reductions in smog levels. Significant uncertainties remain, however. It is unclear why the $\mathrm{HO}_{\mathrm{x}}$ levels are generally underestimated. Although we identify several possible deficiencies in the photochemical mechanism that may contribute to an underprediction of $\mathrm{HO}_{\mathrm{x}}$, these are not sufficient to account for the discrepancy and each is uncertain and requires additional laboratory work to test these mechanisms (e.g., Wennberg 
and Dabdub, 2008). In addition, $\mathrm{NO}_{\mathrm{x}}$ levels are generally much higher at the surface and so it is unclear if $\mathrm{NO}_{\mathrm{x}}$-limited conditions also apply.

Acknowledgements. The authors wish to thank C. M. Roehl for synthesizing the peroxynitric acid for calibration. P. Weibring and A. Fried, D. R. Blake, and R. E. Shetter provided formaldehyde, whole air sample, and solar actinic flux measurements, respectively, which provided constrains for the photochemical box model. The authors also wish to thank the C-130 crew and support team. The $\mathrm{HO}_{2} \mathrm{NO}_{2}$ measurements and their interpretation was made possible with the financial support of NASA (NAG: NNG06GB32B). J. D. C. acknowledges support from the EPA-STAR Fellowship Program (FP916334012). This work has not been formally reviewed by the EPA. The views expressed in this document are solely those of the authors and the EPA does not endorse any products or commercial services mentioned in this publication.

Edited by: S. Madronich

\section{References}

Amelynck, C., Schoon, N., and Arijs, E.: Gas phase reactions of $\mathrm{CF}_{3} \mathrm{O}^{-}$and $\mathrm{CF}_{3} \mathrm{O}^{-} \mathrm{H}_{2} \mathrm{O}$ with nitric, formic, and acetic acid, Int. J. Mass Spectrom., 203, 165-175, 2000.

Amelynck, C., Van Bavel, A. M., Schoon, N., and Arijs, E.: Gas phase reactions of $\mathrm{CF}_{3} \mathrm{O}^{-}$and $\mathrm{CF}_{3} \mathrm{O}^{-} \cdot \mathrm{H}_{2} \mathrm{O}$ and their relevance to the detection of stratospheric $\mathrm{HCl}$, Int. J. Mass Spectrom., 202, 207-216, 2000.

Arnold, S. R., Chipperfield, M. P., and Blitz, M. A.: A threedimensional model study of the effect of new temperaturedependent quantum yields for acetone photolysis, J. Geophys. Res.-Atmos., 110, D22305, doi:10.1029/2005JD005998, 2005.

Atkinson, R., Baulch, D. L., Cox, R. A., Crowley, J. N., Hampson, R. F., Hynes, R. G., Jenkin, M. E., Rossi, M. J., and Troe, J.: Evaluated kinetic and photochemical data for atmospheric chemistry: Volume $\mathrm{I}-$ gas phase reactions of $\mathrm{O}_{\mathrm{x}}, \mathrm{HO}_{\mathrm{x}}, \mathrm{NO}_{\mathrm{x}}$ and $\mathrm{SO}_{\mathrm{x}}$ species, Atmos. Chem. Phys., 4, 1461-1738, 2004, http://www.atmos-chem-phys.net/4/1461/2004/.

Barnes, I., Bastian, V., Becker, K. H., Fink, E. H., and Zabel, F.: Pressure Dependence of the Reaction of $\mathrm{OH}$ with $\mathrm{HO}_{2} \mathrm{NO}_{2}$, Chem. Phys. Lett., 123, 28-32, 1986.

Blake, N. J., Blake, D. R., Simpson, I. J., Meinardi, S., Swanson, A. L., Lopez, J. P., Katzenstein, A. S., Barletta, B., Shirai, T., Atlas, E., Sachse, G., Avery, M., Vay, S., Fuelberg, H. E., Kiley, C. M., Kita, K., and Rowland, F. S.: NMHCs and halocarbons in Asian continental outflow during the Transport and Chemical Evolution over the Pacific (TRACE-P) Field Campaign: Comparison with PEM-West B, J. Geophys. Res.-Atmos., 108, 8806, doi:10.1029/2002JD003367, 2003.

Campos, T. L., Weinheimer, A. J., Zheng, J., Montzka, D. D., Walega, J. G., Grahek, F. E., Vay, S. A., Collins, J. E., Wade, L. O., Sachse, G. W., Anderson, B. E., Brune, W. H., Tan, D., Faloona, I., Baughcum, S. L., and Ridley, B. A.: Measurement of $\mathrm{NO}$ and $\mathrm{NO}_{\mathrm{y}}$ emission indices during SUCCESS, Geophys. Res. Lett., 25, 1713-1716, 1998.

Cantrell, C. A., Edwards, G. D., Stephens, S., Mauldin, L., Kosciuch, E., Zondlo, M., and Eisele, F.: Peroxy radical observations using chemical ionization mass spectrometry during TOPSE, J.
Geophys. Res.-Atmos., 108, 8371, doi:10.1029/2002JD002715, 2003.

Colman, J. J., Swanson, A. L., Meinardi, S., Sive, B. C., Blake, D. R., and Rowland, F. S.: Description of the analysis of a wide range of volatile organic compounds in whole air samples collected during PEM-Tropics A and B, Anal. Chem., 73, 37233731, 2001.

Crounse, J. D., McKinney, K. A., Kwan, A. J., and Wennberg, P. O.: Measurement of gas-phase hydroperoxides by chemical ionization mass spectrometry, Anal. Chem., 78, 6726-6732, 2006.

DeMore, W. B., Sander, S. P., Golden, D. M., Hampson, R. F., Kurylo, M. J., Howard, C. J., Ravishankara, A. R., Kolb, C. E., and Molina, M. J.: Chemical Kinetics and Photochemical Data for Use in Stratospheric Modeling, Evaluation Number 12, JPL Publication 97-4, NASA Jet Propulsion Laboratory, California Institute of Technology, Pasadena, CA 1997.

DuMouchel, W. H. and O'Brien, F. L.: Integrating a Robust Option into a Multiple Regression Computing Environment, Computer Science and Statistics: Proceedings of the 21st Symposium on the Interface, Alexandria, VA, American Statistical Association, 1989.

Emmerson, K. M., Carslaw, N., Carpenter, L. J., Heard, D. E., Lee, J. D., and Pilling, M. J.: Urban atmospheric chemistry during the PUMA campaign 1: Comparison of modelled $\mathrm{OH}$ and $\mathrm{HO}_{2}$ concentrations with measurements, J. Atmos. Chem., 52, 143164, 2005.

Fried, A., Crawford, J., Olson, J., Walega, J., Potter, W., Wert, B., Jordan, C., Anderson, B., Shetter, R., Lefer, B., Blake, D., Blake, N., Meinardi, S., Heikes, B., O’Sullivan, D., Snow, J., Fuelberg, H., Kiley, C. M., Sandholm, S., Tan, D., Sachse, G., Singh, H., Faloona, I., Harward, C. N., and Carmichael, G. R.: Airborne tunable diode laser measurements of formaldehyde during TRACE-P: Distributions and box model comparisons, J. Geophys. Res.-Atmos., 108, 8798, doi:10.1029/2003JD003451, 2003.

Frost, G. J., Fried, A., Lee, Y. N., Wert, B., Henry, B., Drummond, J. R., Evans, M. J., Fehsenfeld, F. C., Goldan, P. D., Holloway, J. S., Hubler, G., Jakoubek, R., Jobson, B. T., Knapp, K., Kuster, W. C., Roberts, J., Rudolph, J., Ryerson, T. B., Stohl, A., Stroud, C., Sueper, D. T., Trainer, M., and Williams, J.: Comparisons of box model calculations and measurements of formaldehyde from the 1997 North Atlantic Regional Experiment, J. Geophys. Res.-Atmos., 107, 4060, doi:10.1029/2001JD000896, 2002.

Fry, J. L., Nizkorodov, S. A., Okumura, M., Roehl, C. M., Francisco, J. S., and Wennberg, P. O.: Cis-cis and trans-perp HOONO: Action spectroscopy and isomerization kinetics, J. Chem. Phys., 121, 1432-1448, 2004.

George, L. A., Hard, T. M., and O'Brien, R. J.: Measurement of free radicals $\mathrm{OH}$ and $\mathrm{HO}_{2}$ in Los Angeles smog, J. Geophys. Res.-Atmos., 104, 11643-11655, 1999.

Gierczak, T., Jimenez, E., Riffault, V., Burkholder, J. B., and Ravishankara, A. R.: Thermal Decomposition of $\mathrm{HO}_{2} \mathrm{NO}_{2}$ (Peroxynitric Acid, PNA): Rate Coefficient and Determination of the Enthalpy of Formation, J. Phys. Chem. A., 109, 586-596, 2005.

Graham, R. A., Winer, A. M., and Pitts, J. N.: Temperature dependence of the unimolecular decomposition of pernitric acid and its atmospheric implications, Chem. Phys. Lett., 51, 215-220, 1977.

Graham, R. A., Winer, A. M., and Pitts, J. N.: Pressure and Temperature Dependence of Unimolecular Decomposition of $\mathrm{HO}_{2} \mathrm{NO}_{2}$, 
J. Chem. Phys., 68, 4505-4510, 1978.

Heard, D. E., Carpenter, L. J., Creasey, D. J., Hopkins, J. R., Lee, J. D., Lewis, A. C., Pilling, M. J., Seakins, P. W., Carslaw, N., and Emmerson, K. M.: High levels of the hydroxyl radical in the winter urban troposphere, Geophys. Res. Lett. 31, L18112, doi:10.1029/2004GL020544, 2004.

Huey, L. G., Hanson, D. R., and Howard, C. J.: Reactions of $\mathrm{SF}_{6}^{-}$ and $\mathrm{I}^{-}$with atmospheric trace gases, J. Phys. Chem., 99, 50015008, 1995.

Huey, L. G., Villalta, P. W., Dunlea, E. J., Hanson, D. R., and Howard, C. J.: Reactions of $\mathrm{CF}_{3} \mathrm{O}^{-}$with atmospheric trace gases, J. Phys. Chem., 100, 190-194, 1996.

Jacob, D. J.: Introduction to Atmospheric Chemistry, Princeton University Press, 1999.

Jaegle, L., Jacob, D. J., Brune, W. H., Faloona, I., Tan, D., Heikes, B. G., Kondo, Y., Sachse, G. W., Anderson, B., Gregory, G. L., Singh, H. B., Pueschel, R., Ferry, G., Blake, D. R., and Shetter, R. E.: Photochemistry of $\mathrm{HO}_{\mathrm{x}}$ in the upper troposphere at northern midlatitudes, J. Geophys. Res.-Atmos., 105, 38773892, 2000.

Jimenez, E., Gierczak, T., Stark, H., Burkholder, J. B., and Ravishankara, A. R.: Reaction of $\mathrm{OH}$ with $\mathrm{HO}_{2} \mathrm{NO}_{2}$ (Peroxynitric Acid): Rate Coefficients between 218 and $335 \mathrm{~K}$ and Product Yields at 298 K, J. Phys. Chem. A., 108, 1139-1149, 2004.

Kanaya, Y., Cao, R. Q., Akimoto, H., Fukuda, M., Komazaki, Y., Yokouchi, Y., Koike, M., Tanimoto, H., Takegawa, N., and Kondo, Y.: Urban photochemistry in central Tokyo: 1. Observed and modeled $\mathrm{OH}$ and $\mathrm{HO}_{2}$ radical concentrations during the winter and summer of 2004, J. Geophys. Res.-Atmos., 112, D21312 doi:10.1029/2007JD008670, 2007.

Kim, S., Huey, L. G., Stickel, R. E., Tanner, D. J., Crawford, J. H., Olson, J. R., Chen, G., Brune, W. H., Ren, X., Lesher, R., Wooldridge, P. J., Bertram, T. H., Perring, A., Cohen, R. C., Lefer, B. L., Shetter, R. E., Avery, M., Diskin, G., and Sokolik, I.: Measurement of $\mathrm{HO}_{2} \mathrm{NO}_{2}$ in the free troposphere during the intercontinental chemical transport experiment - North America 2004, J. Geophys. Res.-Atmos., 112, D12S01, doi:10.1029/2006JD007676, 2007.

Knight, G., Ravishankara, A. R., and Burkholder, J. B.: UV absorption cross sections of $\mathrm{HO}_{2} \mathrm{NO}_{2}$ between 343 and $273 \mathrm{~K}$, Phys. Chem. Chem. Phys., 4, 1432-1437, 2002.

Li, S. P., Matthews, J., and Sinha, A.: Atmospheric hydroxyl radical production from electronically excited $\mathrm{NO}_{2}$ and $\mathrm{H}_{2} \mathrm{O}$, Science, 319, 1657-1660, 2008.

Lurmann, F. W., Lloyd, A. C., and Atkinson, R.: A Chemical Mechanism for Use in Long-Range Transport Acid Deposition Computer Modeling, J. Geophys. Res.-Atmos., 91, 10905-10936, 1986.

Macleod, H., Smith, G. P., and Golden, D. M.: Photodissociation of Pernitric Acid $\left(\mathrm{HO}_{2} \mathrm{NO}_{2}\right)$ at $248 \mathrm{~nm}$, J. Geophys. Res.-Atmos., 93, 3813-3823, 1988.

Madronich, S. and Flocke, S.: The role of solar radiation in atmospheric chemistry, in: Handbook of Environmental Chemistry, edited by: Boule, P., Springer, 1-26, 1998.

Martinez, M., Harder, H., Kovacs, T. A., Simpas, J. B., Bassis, J., Lesher, R., Brune, W. H., Frost, G. J., Williams, E. J., Stroud, C. A., Jobson, B. T., Roberts, J. M., Hall, S. R., Shetter, R. E., Wert, B., Fried, A., Alicke, B., Stutz, J., Young, V. L., White, A. B., and Zamora, R. J.: $\mathrm{OH}$ and $\mathrm{HO}_{2}$ concentrations, sources, and loss rates during the Southern Oxidants Study in Nashville, Tennessee, Summer 1999, J. Geophys. Res.-Atmos., 108, D194617, doi:10.1029/2003JD003551, 2003.

Miller, E. R. and R. B. Friesen: Standard output data products from the NCAR Research Aviation Facility, NCAR RAF Bulletin 9, http://www.eol.ucar.edu/raf/Bulletins/bulletin9.html., 1985.

Murphy, J. G., Thornton, J. A., Wooldridge, P. J., Day, D. A., Rosen, R. S., Cantrell, C., Shetter, R. E., Lefer, B., and Cohen, R. C.: Measurements of the sum of $\mathrm{HO}_{2} \mathrm{NO}_{2}$ and $\mathrm{CH}_{3} \mathrm{O}_{2} \mathrm{NO}_{2}$ in the remote troposphere, Atmos. Chem. Phys., 4, 377-384, 2004, http://www.atmos-chem-phys.net/4/377/2004/.

Niki, H., Maker, P. D., Savage, C. M., and Breitenbach, L. P.: Fourier transform IR spectroscopic observation of pernitric acid formed via $\mathrm{HOO}+\mathrm{NO}_{2} \rightarrow \mathrm{HOONO}_{2}$, Chem. Phys. Lett., 45, 564-566, 1977.

Olson, J. R., Crawford, J. H., Chen, G., Fried, A., Evans, M. J., Jordan, C. E., Sandholm, S. T., Davis, D. D., Anderson, B. E., Avery, M. A., Barrick, J. D., Blake, D. R., Brune, W. H., Eisele, F. L., Flocke, F., Harder, H., Jacob, D. J., Kondo, Y., Lefer, B. L., Martinez, M., Mauldin, R. L., Sachse, G. W., Shetter, R. E., Singh, H. B., Talbot, R. W., and Tan, D.: Testing fast photochemical theory during TRACE-P based on measurements of $\mathrm{OH}, \mathrm{HO}_{2}$, and $\mathrm{CH}_{2} \mathrm{O}$, J. Geophys. Res.-Atmos., 109, D15S10, doi:10.1029/2003JD004278, 2004.

Olson, J. R., Crawford, J. H., Chen, G., Brune, W. H., Faloona, I. C., Tan, D., Harder, H., and Martinez, M.: A reevaluation of airborne $\mathrm{HO}_{\mathrm{x}}$ observations from NASA field campaigns, J. Geophys. Res.-Atmos., 111, D10301, doi:10.1029/2005JD006617, 2006.

Okumura, M. and Sander, S. P: Gas-Phase Formation Rates of Nitric Acid and its Isomers under Urban Conditions, State of California Air Resources Board, 2005.

Ravishankara, A. R., Dunlea, E. J., Blitz, M. A., Dillon, T. J., Heard, D. E., Pilling, M. J., Strekowski, R. S., Nicovich, J. M., and Wine, P. H.: Redetermination of the rate coefficient for the reaction of $\mathrm{O}\left({ }^{1} \mathrm{D}\right)$ with $\mathrm{N}_{2}$, Geophys. Res. Lett., 29, 1745, doi:10.1029/2002GL014850, 2002.

Ren, X. R., Harder, H., Martinez, M., Lesher, R. L., Oliger, A., Simpas, J. B., Brune, W. H., Schwab, J. J., Demerjian, K. L., He, Y., Zhou, X. L., and Gao, H. G.: $\mathrm{OH}$ and $\mathrm{HO}_{2}$ chemistry in the urban atmosphere of New York City, Atmos. Environ., 37, 3639-3651, 2003.

Ren, X. R., Brune, W. H., Mao, J. Q., Mitchell, M. J., Lesher, R. L., Simpas, J. B., Metcalf, A. R., Schwab, J. J., Cai, C. X., Li, Y. Q., Demerjian, K. L., Felton, H. D., Boynton, G., Adams, A., Perry, J., He, Y., Zhou, X. L., and Hou, J.: Behavior of $\mathrm{OH}$ and $\mathrm{HO}_{2}$ in the winter atmosphere in New York City, Atmos. Environ., 40, S252-S263, 2006.

Ren, X. R., Olson, J. R., Crawford, J. H., Brune, W. H., Mao, J. Q., Long, R. B., Chen, Z., Chen, G., Avery, M. A., Sachse, G. W., Barrick, J. D., Diskin, G. S., Huey, L. G., Fried, A., Cohen, R. C., Heikes, B., Wennberg, P. O., Singh, H. B., Blake, D. R., and Shetter, R. E.: $\mathrm{HO}_{\mathrm{x}}$ chemistry during INTEX-A 2004: Observation, model calculation, and comparison with previous studies, J. Geophys. Res.-Atmos., 113, D05310, doi:10.1029/2007JD009166, 2008.

Roehl, C. M., Nizkorodov, S. A., Zhang, H., Blake, G. A., and Wennberg, P. O.: Photodissociation of Peroxynitric Acid in the Near-IR, J. Phys. Chem. A., 106, 3766-3772, 2002. 
Rothman, L. S., Jacquemart, D., Barbe, A., Benner, D. C., Birk, M., Brown, L. R., Carleer, M. R., Chackerian, C., Chance, K., Coudert, L. H., Dana, V., Devi, V. M., Flaud, J. M., Gamache, R. R., Goldman, A., Hartmann, J. M., Jucks, K. W., Maki, A. G., Mandin, J. Y., Massie, S. T., Orphal, J., Perrin, A., Rinsland, C. P., Smith, M. A. H., Tennyson, J., Tolchenov, R. N., Toth, R. A., Vander Auwera, J., Varanasi, P., and Wagner, G.: The HITRAN 2004 molecular spectroscopic database, J. Quant. Spectrosc. Ra., 96, 139-204, 2005.

Sander, S. P., Friedl, R. R., DeMore, W. B., Golden, D. M., Kurylo, M. J., Hampson, R. F., Huie, R. E., Moortgat, G. K., Ravishankara, A. R., Kolb, C. E., and Molina, M. J.: Chemical Kinetics and Photochemical Data for Use in Stratospheric Modeling Supplement to Evaluation 12: Update of Key Reactions, JPL Publication 00-3, NASA Jet Propulsion Laboratory, California Institute of Technology, Pasadena, CA, 2000.

Sander, S. P., Friedl, R. R., Golden, D. M., Kurylo, M. J., Huie, R. E., Orkin, V. L., Moortgat, G. K., Ravishankara, A. R., Kolb, C. E., Molina, M. J., and Finlayson-Pitts, B. J.: Chemical Kinetics and Photochemical Data for Use in Atmospheric Studies, Evaluation Number 14 JPL Publication 02-25, NASA Jet Propulsion Laboratory, California Institute of Technology, Pasadena, CA, 2003.

Sander, S. P., Friedl, R. R., Golden, D. M., Kurylo, M. J., Moortgat, G. K., Keller-Rudek, H., Wine, P. H., Ravishankara, A. R., Kolb, C. E., Molina, M. J., Finlayson-Pitts, B. J., Huie, R. E., and Orkin, V. L.: Chemical Kinetics and Photochemical Data for Use in Atmospheric Studies, Evaluation Number 15 JPL Publication 06-2, NASA Jet Propulsion Laboratory, California Institute of Technology, Pasadena, CA, 2006.

Seinfeld, J. H. and Pandis, S. N.: Atmospheric Chemistry and Physics, 2nd ed., John Wiley \& Sons, Inc., 2006.

Shetter, R. E. and Muller, M.: Photolysis frequency measurements using actinic flux spectroradiometry during the PEM-Tropics mission: Instrumentation description and some results, J. Geophys. Res.-Atmos., 104, 5647-5661, 1999.

Shirley, T. R., Brune, W. H., Ren, X., Mao, J., Lesher, R., Cardenas, B., Volkamer, R., Molina, L. T., Molina, M. J., Lamb, B., Velasco, E., Jobson, T., and Alexander, M.: Atmospheric oxidation in the Mexico City Metropolitan Area (MCMA) during April 2003, Atmos. Chem. Phys., 6, 2753-2765, 2006, http://www.atmos-chem-phys.net/6/2753/2006/.
Slusher, D. L., Pitteri, S. J., Haman, B. J., Tanner, D. J., and Huey, L. G.: A chemical ionization technique for measurement of pernitric acid in the upper troposphere and the polar boundary layer, Geophys. Res. Lett., 28, 3875-3878, 2001.

Smith, C. A., Molina, L. T., Lamb, J. J., and Molina, M. J.: Kinetics of the Reaction of $\mathrm{OH}$ with Pernitric and Nitric Acids, Int. J. Chem. Kin., 16, 41-55, 1984.

Street, J. O., Carroll, R. J., and Ruppert, D.: A Note on Computing Robust Regression Estimates via Iteratively Reweighted Least Squares, The American Statistician, 42, 152-154, 1988.

Trevor, P. L., Black, G., and Barker, J. R.: Reaction Rate Constant for $\mathrm{OH}+\mathrm{HOONO}_{2} \rightarrow$ Products over the Temperature Range 246 to 324 K, J. Phys. Chem., 86, 1661-1669, 1982.

Weinheimer, A. J., Montzka, D. D., Campos, T. L., Walega, J. G., Ridley, B. A., Donnelly, S. G., Keim, E. R., Del Negro, L. A., Proffitt, M. H., Margitan, J. J., Boering, K. A., Andrews, A. E., Daube, B. C., Wofsy, S. C., Anderson, B. E., Collins, J. E., Sachse, G. W., Vay, S. A., Elkins, J. W., Wamsley, P. R., Atlas, E. L., Flocke, F., Schauffler, S., Webster, C. R., May, R. D., Loewenstein, M., Podolske, J. R., Bui, T. P., Chan, K. R., Bowen, S. W., Schoeberl, M. R., Lait, L. R., and Newman, P. A.: Comparison between DC-8 and ER-2 species measurements in the tropical middle troposphere: $\mathrm{NO}, \mathrm{NO}_{\mathrm{y}}, \mathrm{O}_{3}, \mathrm{CO}_{2}, \mathrm{CH}_{4}$, and $\mathrm{N}_{2} \mathrm{O}$, J. Geophys. Res.-Atmos., 103, 22087-22096, 1998.

Wennberg, P. O. and Dabdub, D.: Atmospheric chemistry - Rethinking ozone production, Science, 319, 1624-1625, 2008.

Wert, B. P., Fried, A., Rauenbuehler, S., Walega, J., and Henry, B.: Design and performance of a tunable diode laser absorption spectrometer for airborne formaldehyde measurements, J. Geophys. Res.-Atmos., 108, 4350 doi:10.1029/2002JD002872, 2003.

Zabel, F.: Unimolecular Decomposition of Peroxynitrates, Zeitschrift für Physikalische Chemie-International, Journal of Research in Physical Chemistry \& Chemical Physics, 188, 119142, 1995. 